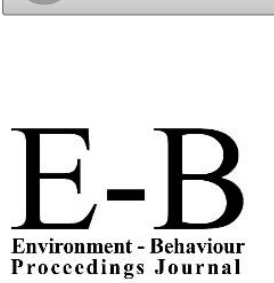

\author{
ASLI QoL 2017 \\ AicQoL2017Bangkok \\ $5^{\text {th }}$ AMER International Conference on Quality of Life \\ Nouvo City Hotel, Bangkok, Thailand, 25-27 February 2017
}

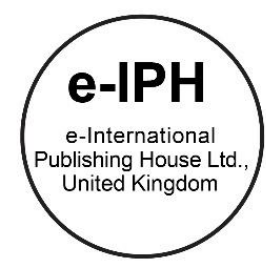

\title{
Urban Picnic: Relations among actors
}

\author{
Achmad Hery Fuad ${ }^{1 *}$, Yandi Andri Yatmo² \\ 1 Doctoral Student, Dept of Architecture Faculty of Engineering Universitas Indonesia, Depok 16424, Indonesia \\ ${ }^{2}$ Professor of Architecture
}

\begin{abstract}
This paper attempts to reveal relations among actors at urban public spaces. We examined the relations by exploring activities of the urban society in picnic activity. In studying the relations among actors we use the actor - network theory Latour (2007). We conducted data collection strategy such as drifting from psychogeography Debord $(1955,1992)$ and bodily experience Pallasmaa $(2012)$. The findings are the relations among actors within picnic activities in urban spaces shows a different kind of relations. The exploration of picnic activities on urban space shows us the relationships among users, events, spaces defines a variety of changes in the function of urban spaces.
\end{abstract}

Keywords: urban space; urban picnic; relations; space

ISSN: 2398-4287@ 2017. The Authors. Published for AMER ABRA by e-International Publishing House, Ltd., UK. This is an open access article under the CC BYNC-ND license (http://creativecommons.org/licenses/by-nc-nd/4.0/). Peer-review under responsibility of AMER (Association of Malaysian Environment-Behaviour Researchers), ABRA (Association of Behavioural Researchers on Asians) and cE-Bs (Centre for Environment-Behaviour Studies), Faculty of Architecture, Planning \& Surveying, Universiti Teknologi MARA, Malaysia.

\subsection{Introduction}

Suchday, et.al (2006) explains there is a correlation between stress, the chronical problem of urban poor with the quality of the environment. Pressman, et.al (2009) states usage of leisure time for leisure activity is good from the view of psychosocial. The activity at leisure time is also worthy for health and well-being of urban residents. The picnic is an activity to get fun, joy, and also as media to get health which is sometimes filled with sports activity (Hern, 1989). Hence picnic as one of the recreation activity to get joy and health is important to discuss in increasing the quality of life or urban residents

Picnic usually is done in natural space, some of the research examines characteristic of the location for picnic activities, which is dominated by its location out of town as natural location with its beautiful scenery includes: riverside, beach, edge of the forest, lakeside, mountain range and countryside (Miller, 1989; Hern, 1989; White, 2009; \& Shand, 1996). Misra (1988) explains the relation between human and nature, particularly in savouring its atmosphere. However picnic activities not only done at out of town but also in urban spaces such as urban park, historical monument and church's open space (Ellis and Ellis, 1983; Hern, 1989).

In Jakarta specially in area called Hotel Indonesia circle (Bundaran HI) every Sunday during car free day event many of urban residents come to this place. They gather, running, jogging, cycling, parenting, chit-chat, eating, playing, gymnastic, take pictures, playing music, perform. They jaywalk, sit, and enjoy the ambiance. They use pool and its edge, street and the pedestrian way as space and place for their activities. Actually Hotel Indonesia circle is a circle which consist of rounded pool of welcome statue of Jakarta, street surround the pool and also the pedestrian way. The street is one of the main street in Jakarta, everyday this street is full with many kind of vehicles. This space is not addressed as picnic space, it is circulation space for vehicle. However Hotel Indonesia circle every Sunday full of people, they use its urban space as picnic space.

There is merely inconsiderable research about the picnic in urban space, nevertheless, research about the picnic in urban space which is not intended for picnic activity is only examined by Sankalia (2014). It is about production of space and bias of attitude of townsfolk. Therefore this paper will discuss urban picnic related to the spatial mechanism which happens by the relation among

\footnotetext{
${ }^{*}$ Corresponding author. Tel.: +62217863512

E-mail address:achmad.hery@ui.ac.id, heryfuad@gmail.com
}

ISSN: 2398-42870 2017. The Authors. Published for AMER ABRA by e-International Publishing House, Ltd., UK. This is an open access article under the CC BYNC-ND license (http://creativecommons.org/licenses/by-nc-nd/4.0/). Peer-review under responsibility of AMER (Association of Malaysian Environment-Behaviour Researchers), ABRA (Association of Behavioural Researchers on Asians) and CE-Bs (Centre for Environment-Behaviour Studies), Faculty of Architecture, Planning \& Surveying, Universiti Teknologi MARA, Malaysia.

DOI: http://dx.doi.org/10.21834/e-bpj.v2i5.669 
actors/actant particularly in urban spaces which is not intended for the picnic. This paper is addressed to fulfill the emptiness of research about urban spaces in architectural science.

\subsection{Research Objective}

The fact of Hotel Indonesia circle in Jakarta shows us that urban spaces which is not intended for picnic activities could become a picnic space. Then we come to the question: "How the space for vehicular circulation could become space for picnic?" To answer that question, in our study we focus on several matter such as: relation among actors, spatial mechanism and transformation of space. Therefore our research objective are:

- to reveal the relations among actors in urban picnic in the city.

- to identify how the relation among actors create particular spatial mechanism that leads to transformation of urban space.

\subsection{Location of Study}

\subsection{Bundaran Hotel Indonesia}

Bundaran Hotel Indonesia or Hotel Indonesia Circle area is the famous place to Jakarta's residence. Located on the axis M. H Thamrin street and Sudirman street, which became the main artery road connecting Jakarta central area to the area of South Jakarta. Bundaran Hotel Indonesia with a Selamat Datang statue is also a landmark of Jakarta. Luxurious shopping malls like Plaza Indonesia, Grand Indonesia, star hotels such as the Grand Hyatt Aryaduta, Hotel Indonesia Kempinski, and Pullman also in around Bundaran Hotel Indonesia. Urban space that created in Bundaran Hotel Indonesia is an abstract space, space according to Lefebvre (1991) is the space where power and capital gathered.

Every Sunday morning between 06.00 a.m to 11.00 a.m have this area become a huge open space full of the occupant, visitor, many kinds of communities. At every Sunday morning Bundaran HI, Thamrin street and Sudirman street free from vehicles and use as Car Free Day area. Many visitors, occupant, urban resident doing their activities such as sport, jogging, jaywalking, cycling, parenting, sitting while watching passer-by, events, take a picture of the landmark and urban scenic view, playing, chit-chat, gathering, eating and drinking, and also shopping.

\subsection{Taman Suropati}

Suropati Park is a park as an integral part of Menteng area built by Bouwmaatschappij N.V de Bouwploeg with Moojen as initiators, the development work of this area began in 1911 (Heuken and Pamungkas, 2001. p. 22). Suropati Park now becomes a city park in the Municipality of Central Jakarta. Having a fairly old age, more than a hundred years old. The park is overgrown with the huge tree and refreshing shade of surrounding air. Suropati Park is one of the best city parks in Jakarta, the park is inseparable from the elite settlements in Jakarta, Menteng. The area is known as a garden city in Indonesia. Suropati Park and other parks in Menteng area are part of the lungs of the city. It is part of the twenty-three parks in Menteng area (Heuken and Pamungkas, 2001).

This park at weekend particularly Saturday evening and Sunday morning is filled with many visitors. On Sunday morning there are many guests, users are jogging, yoga, playing, parenting, gathering, chit-chat, playing music, drawing together, exercise violin, eating and also dating.

\subsection{Methodology}

\subsection{Collecting Data}

This research consist of several parts, first is to gather information about the common picnic, its location, activities and also the picnicker, we collect that information from the journal, poetry and pictures about the picnic. Also we gather information about the usage of urban spaces in Jakarta through collecting data from media such as newspaper, and social media. That activity is to gather information where is the popular place for outdoor activities in Jakarta, what kind of activities that the Jakarta resident do during their leisure time. With whom they do their leisure activities. With that information we make our field survey's plan. We choose two location for our field survey, first is Hotel Indonesia circle, an urban space is not addressed for picnic and the second is Taman Suropati (Suropati Park) a garden which is devised for outdoor activities of the urban resident. We conduct field survey in two different space with it's different character.

\subsection{Drifting}

In order to reveal relation among actor and its spatial mechanism we use drifting from Debord $(1955,1992)$. Drifting is a method in psychogeography which is develop by Debord. With the drifting method we do picnic as wanderer without the exact destination. This method activates the body and mind as a recipient of stimuli, perceptions and reactions to the action indicated by the space and place. This method does not dictate the body and mind to direct someone towards a certain goal. Therefore when we conduct the survey with this method we will stop, sit and watch something that attracts us because of the activity, events, space, place or something is interesting to explore. We wrote notes and marked it on a map, also took pictures. This information for instance: space, events or 
activities will be check again at next visit or next field survey. The purpose of using drifting method is to mark the activities, the space, something hidden or attractive.

\subsection{Bodily Experience}

To explore the space we also use the bodily experience from Pallasmaa (2012) as our method. My body remembers who I am and how I am located in the world. My body is truly the navel of my world, not in the sense of the viewing point of the central perspective, but as the very locus of reference, memory, imagination and integration (Pallasmaa, 2012). We use our body, our senses to feel the space and place. Sometimes we sit, and do activities as picnicker and to record what we feel, we make notes and also take pictures. Those data is gathered in map, notes and picture as visual record. Sometimes we interview the picnickers. But this is one of the obstacle of the survey, we could not meet the same person every time we do field survey. In order to get rich and thick data we conduct the survey at every Sunday morning from 07.00 a.m to 11.00 a.m around 40 times during 2013 to 2016.

\subsection{Actor Network Theory}

There many entities to see and explore in the field. Visitors as runners, joggers, cyclist, hawkers, watchers, man and woman, children, children and their parents, teenagers, boys and girls, the elderly, association, clubs, company employee, hobbyist, police, sketch group, dance group, violin orchestra, band, and also officer whose in charge to keep the environment clean. We also watch the space, street, pool, pedestrian way, fence, edge of the pool, edge of the pedestrian way, bench, trees, grass field, shadow, climate, ground surface, sitting location, playing music location, parenting location, place for taking pictures, teenagers sitting location, elderly sitting location, family sitting location, club and association location, many activities and also not limited to car and motor cycle park location.

How we approach those many entities? Pint (2010) in his study using Actors Network Theory to discuss the program in the interior. According to Pint,, interaction and complex transformation of a diverse program requires a versatile and dynamic approach. Pint sees Actors Network Theory, a theory that emphasizes the involvement, the role of the influence of artifacts in human behavior, and action is the result of a combination of hybrid in which ideas, institutions, and people to operate the networks dynamically according to dissect complex programs in the interior. Various programs are seen as actors who have their respective roles. In the discussion on performativity Taylor (2010) also uses Actors Network Theory approach, which states as follows: "In Actor Network Theory the assertion is that all elements in any interaction should be regarded as actors (or actants) which do not simply", sometimes 'express' power relations, 'symbolize' social hierarchies, 'reinforce' social inequalities, transport social power, 'objectify' inequality, and 'reify' gender relations" but in Latour's conception they can actually be said to be "at the origin of social activity." (Latour, 2005 in Taylor, 2010).

Therefore to see the role, participation, involvement, relation, spatial mechanism and transformation of the entity we use actor network theory from Latour $(1996,2007)$. Anything that does modify a state of affairs by making difference is an actor- or, if has no figuration yet, an actant (Latour, 2007, pp. 72). Then with actors network Theory approach all those involved in the activities of a picnic in the urban open space such as users, visitors, vendors, police, runners, joggers, performers, family and whose are human can be categorized into actor, the space, element of space, climate, city icon, scenic city view, rules, time, street, pedestrian way, edge of the pool, edge of the pedestrian way, trees, shadow, camera, bicycle, gadget (mobile phone), formal and informal rules are actant.

\subsection{Analyze the Data}

In purpose to analyze the data we use the qualitative method and grounded theory. With the qualitative method we reveal the hidden meaning, unseen characteristic, multiple interpretation, invisible connotations, unheard voices. The qualitative research proposes complex explanations and also try to describe with the meaning of networks in detail.

The purpose of grounded theory is to find the deep explanation, more than just explanation and to develop a theory, an abstract, analysis schema from the process (or action, or interaction). Strauss \& Corbin (1990). The expert of grounded theory states the theory should be "grounded" within field data, particularly in action, interaction and social process of the human. Therefore grounded theory available and exist for producing a theory (completed with hypothesis and diagram) from an action, interaction or process through the relation of categorized information, upon data which is collected from individual.(Creswell, 2007).

\subsection{Picnic's Activities in Jakarta's Urban Spaces}

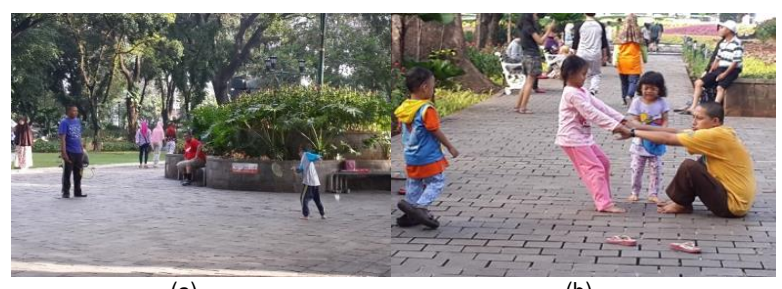

(a)

(b)

Fig. 1 (a): Playing Badminton; (b) Parenting and Playing

(Source: Achmad Hery Fuad) 
In Fig.1(a) Father and his child playing badminton together. For playing badminton, they need an ample space. Within this activity shows us that there is a relation between father and child, without their relation, without their togetherness they can not play badminton. Therefore the relation between father and children is important. With the wide horizontal plane, they can easily move, run and jump in playing badminton. The relation between the players and the wide horizontal plane give the players flexibility within their activity and movement. Then the relation between the horizontal plane and the natural horizontal roof (the lush foliage) give the adequate distance between ground and roof. This relation also gives the players easiness and flexibility in their activities. Besides it, the relation also triggered the transformation of the function of the space, in this case from park to become temporary sports ground.

The relation among actors/ actant such as players, activity, horizontal plane and horizontal roof (lush foliage) as wide and tall space give and permit the human to do their activities as they intended. The mechanism of relation among human, space, and element of space give human flexibility, easiness also supports to do their intentional activities, also the relation among the actors define the changes in the function of space.

In Fig.1 (b) Father and his children are playing together. This is also the parenting activity for the father on Sunday morning. They took place in Taman Suropati. Within this activity the father and his children show their relationship, this relation also shows us the relation of the activity with the plaza as the playing ground. The wide plaza supports them with ample space, make them easy to move, to play and to choose the place where they held their activities. The plaza as an open space without visual barrier also give the parent easiness to watch the surrounding, the relation between parent and open space give the user high visibility and secure feeling.

The mechanism of relation among the actors/actant in this case such as the parent, the open space, the wide open space, the visual barrier-free open space defines the change of space from the plaza to become the playing and parenting ground. The mechanism of relation within this space gives the space or the user to change the function of the space.

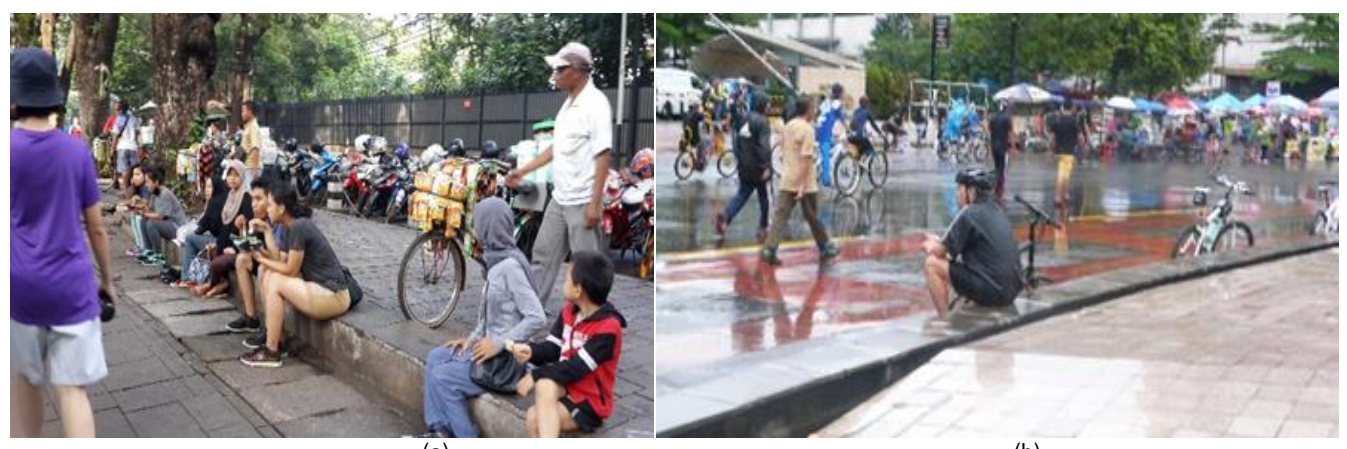

(a)

(b)

Fig.2 (a) Eating and Watching; (b) Watching events (source: Achmad Hery Fuad)

Within Fig.2(a) we could see the activities of the teenager. They sitting on the pedestrian way which is the border of Taman Surapati. They sat there in the morning around 8.30 a.m. Some of them are couples, boy, and girls. They eat light breakfast as the vegetable, rice and peanut sauce (known as nasi pecel). While eating they watching the passer-by and the center of the park. In the middle between the two couples sit at the pedestrian way the seller of pecel.

The activities of the teenager need a relation between them, gathering, conversation and having breakfast. The pedestrian way function is for people circulation, but in Taman Surapati it is used as sitting area for the users. The relation between boys and girls is supported by the pedestrian way. The relation between pecel seller and the buyers also supported by the pedestrian way. The size and the distance of the pedestrian way from the ground make the pedestrian way a comfort sitting place. The size of the pedestrian way gives the flexibility for the user as for where they want to sit. The relation among the teenager, pecel seller and pedestrian way and also define the transformation of the pedestrian way to becoming sitting area and eating area.

The center of theTaman Suropati is a ground with green foliage, one of the beautiful part of the garden. The garden play as the urban scenic, people enjoy watching the scenery. The relation between the couples as the users and the center of the park define the role of the garden as the urban scenic.

The relation among the teenager, pedestrian way and center of the park also define the transformation of the pedestrian way to becoming sitting and watching area. The mechanism of relation among actors as the teenager, pecel seller, pedestrian way, and center of the park define the variation or alteration of function of the pedestrian way from space for circulation become space for sitting, gathering, eating, chit-chat and watching. The mechanism of relation among actors as the user, the space, element of space with their inside flexibility and it's comfort support space to transform its function to another function.

In Fig.2(b) At a cloudy Sunday morning during Car Free Day event, a man with his helmet sit down at the edge of the pool of Bundaran $\mathrm{HI}$ ( $\mathrm{HI}$ Circle). His bike lies at the side of the pool. The street is wet with rain water. The man sit there, rest and watch the passer-by, also watch the scenic view of the building at surrounding Bundaran $\mathrm{HI}$. This man came to Bundaran $\mathrm{HI}$ although at that time rain was poured down. The man sits alone at the border of the pool with the street, seems to enjoy the activities of the people such as jogging, running, walking, cycling at Bundaran $\mathrm{HI}$. His activity describes the relation between him and the event at Bundaran $\mathrm{HI}$, also shows the relation between him and the urban scenic. He sits at the edge of the pool, the border becomes the sitting area. The relation between the man and the border shows the flexibility of the edge to become a space for sitting. 
The relation between the edge of the pool and the street around Bundaran $\mathrm{HI}$ show its role to provide ample space between the pool and the buildings, a space for urban resident activities. The relation among actor as the user, the event, the urban scenic shows the space for vehicle transform to become space for watching, for enjoying urban scenic.

The mechanism of relation among actors, as the users, events, the edge of the pool, street, surrounding building alter the street around Bundaran $\mathrm{HI}$ to become an urban destination with its myriad activities. It also transfers Bundaran $\mathrm{HI}$ to become space to enjoy urban scenic view and events. The mechanism of relation among users, events, and spaces lead the spaces to become new spaces.

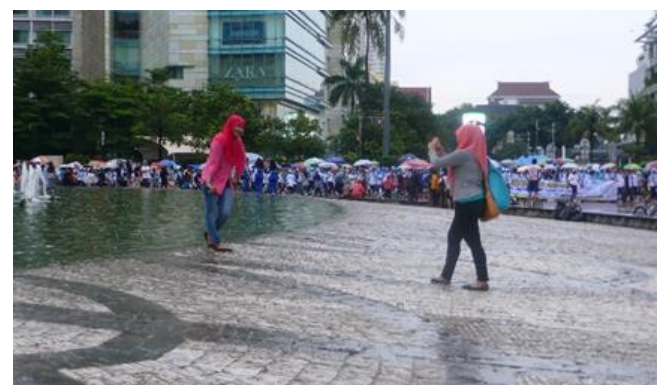

(a)

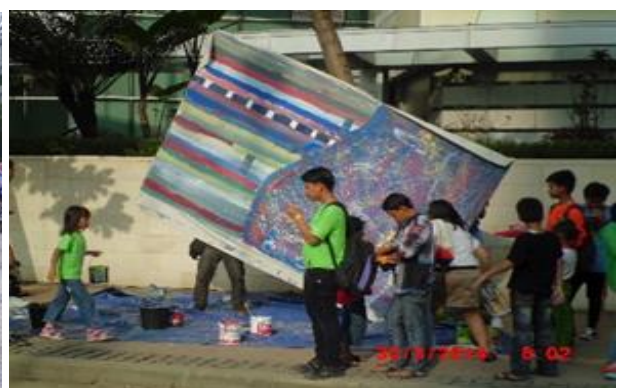

(b)

Fig.3 (a) Take Pictures; (b) Painting together (Source: Achmad Hery Fuad)

At a cloudy Sunday morning during Car Free Day event two girls are standing in the middle of the pool of Bundaran HI. See Fig.3(a).They take a picture with the background of welcome statue and Bundaran $\mathrm{HI}$ surrounding. To take a picture they need a camera, space and also object as the background. For the object and the background, people need an interesting thing or beautiful scenery. Their activity shows the relation between the welcome statue and its surrounding with the girls. The welcome statue becomes the background of the photography activity, and the middle of the pool become the foreground of that activity. The relation between the girls and the distance between the girls and the object and its surrounding define the alteration of the welcome pool to become space of urban scenic view. Therefore the relation mechanism among the user of space, the activity of taking a picture, the foreground, background or the surrounding define the transformation the Bundaran $\mathrm{HI}$ to become an interesting popular place to take a picture of urban scenery. Also, the mechanism of relation among the users, events, and space change the function of Bundaran $\mathrm{HI}$ to become space for photography activity.

Fig.3(b). At the bright Sunday morning during Car Free Day event a number of teenagers stand at the street near Bundaran HI, they bring a canvas and paint it together with the passer-by as the participant. The street gives the user plenty of space, and give the flexibility to use it for their needs and desire. The street relation with the art activity by the teenager show that the street becomes an expression open space. The relation of the street with the teenager is showing the street as the strategic place for them, a place for painting together, a place to get the participant. The relation between the teenager and the street show that the street transform from vehicle's circulation space become the interactive space for the user. The relation between the teenager and the participant is a kind of interactive activity.

The flexibility of space usage as the mechanism of the relation among actors define the changing of the street become an expression and an interactive space.

\subsection{Conclusion}

\section{Relation among actors/actant}

At the picnic activities in the urban spaces occurred diverse relationships among actor and actant. There is the relation between actor with the actor such as a father with children in parenting activity show relation of togetherness; friends with friends in chit-chat activity shows the relation of friendship ; teenagers with food vendors shows the relation of demand and supply of food; teenagers and participants shows relation of involvement. Also occurs relation among actors, actor and actant such as the relations between the father and his children with an a open space shows relation of parenting, accommodation and availability of space for parenting, playing; with a ground surface that is clean, with a space with high visibility shows relation of accommodation of comfort and secure space. Also among adolescents with the participation of their activities also with scenic view, open space, crowd shows the relation among them about the need for interesting and attractive view. Therefore picnic activities in urban spaces show us the different kind relation between actor and actor and among actors and actant .

\section{Spatial Mechanism}

Relation among actor to actor, actors with actant showing cooperation among them toward action of the actor/user goals. Cooperation among actors and actant or spatial mechanism among actors and actant produces space that meets the needs of the users, visitors, and picnicker for instance a spacious-interesting-attractive space, which gave them the easiness to move, safe, comfort, high visibility 
and flexible space to use for the variety of users activities. Therefore spatial mechanism which is happening because of relation among actor/ actant within their picnic activities fulfill the needs of the user for picnic space in urban spaces.

\section{Transformation of space}

The relation among actors/ actant in picnic activities define the changes in the function of space. Therefore spatial mechanism of relation among actor/ actant lead the spaces to become new spaces of urban picnic with its diverse new function.

\subsection{Recommendation}

This research is about the relation among actor/actant in order to understand how spatial mechanism of it define the transformation of urban space leads to new urban space for the picnic activity. However, to understand the whole spatial mechanism of urban space transformation, we also need to explore the reaction mechanism among actor/actant. Therefore in order to understand the production of new urban space, we propose research about reaction mechanism in picnic activities in urban spaces.

\section{Acknowledgements}

This paper is part of Achmad Hery Fuad Ph.D. dissertation which was still in the initial stage. The research was funded by Ministry of Research, Technology and Higher Education of the Republic of Indonesia, under the Domestic Graduate Scholarship (BPP-DN) scheme. We would like to express our gratitude to all who have contributed to this paper, especially the users and visitors of Bundaran Hotel Indonesia, Taman Surapati in Jakarta, and all colleagues in the Department of Architecture, Faculty of Engineering, University of Indonesia.

\section{References}

Boskin, Joseph. (1965). Associations and Picnics as Stabilizing Forces n Southern California. California Historical Society Quarterly, 44(1), pp.17-26.

Brandon, John. (2008). The Picnic. Mississipi Review, 36(3), Literary Magazine, pp. 88-99

California Snapshot. (1983). California Snapshots Source: California History, 62.California Historical Society

Cohen-Cruz, J. (Ed.). (1998). Radical street performance: An international anthology. London, England: Routledge.

Creswell, John,W.(2007).Qualitative Inquiry \& Research Design: Choosing Among Five Approaches, 2 ${ }^{\text {nd }}$ ed. California: Sage Publication.

Corbin, J.\& Strauss, A. Grounded Theory Research: Procedures, Canon, and Evaluative Criteria. Qualitative Sociology, Vol.13, No.1,1990, pp. 3-21.

Debord, Guy in Andreotti, Libero. And Costa, Xavier. (1996). Theory of the Derive and other situasionist writing on the city. Barcelona: Museu d'Art Contemporani de Barcelona ACTAR. Pp. 18-21. 22-27.

Gardner, Diana. (1961). The Picnic. The Transatlantic Review, 6, pp. 103-112.

Hern, W, Ellen, Mary. (1989). Picnicking in the Northeastern United States 1840-1900. Winterthur Portfolio, 24(2/3), pp. 139-152.

Heuken S.J., Adolf. (1997). Tempat-tempat bersejarah di Jakarta. Jakarta: Cipta Loka Caraka.

Heuken S.J., Adolf, and Pamungkas, Grace, ST. (2001). Menteng: 'Kota Taman' pertama di Indonesia. Jakarta: Cipta Loka Caraka.

Latour, Bruno. On Actor-Network Theory. A Few Clarifications Plus More Than A Few Complications. http://www.cours.fse.ulaval.ca/edc-65804/latour.pdf downloaded on March 2nd 2017.

Latour, Bruno. (2007). Reassembling the Social: An Introduction to Actor-Network-Theory. Oxford: Oxford University Press.

Lee, Suu-Hsin. (1996). Urban Women's Leisure: Typology and Constraints. World Leisure \& Recreation, 38 (4), pp. 31-34.

Lefebvre, Henri. (1991). The Production of Space (English ed.). Oxford: Blackwell Publishers Ltd.

Lepori, Bianca. R and Franck, A, Karen. (2000). Architecture Inside Out. Toronto: Wiley-Academy.

Miller, L, Angela. (1989). Nature's Transformation: The Meaning of the Picnic Theme in Nineteenth-Century- American Art. Winterthur Portfolio, 24(2/3). The University of Chicago Press.

Misra, Soubhagya. (1988). Picnic at Taptapani. Indian Literature, 31(2), pp. 46-49 Published by: Sahitya Akademi

Ness, Mrs. Patrick. (1941). Lake Chad Picnic. Journal of the Royal African Society, 40(161), pp. 316-326.

Pallasmaa, Juhani. (2012). The Eyes of The Skin Architecture and The Senses. John Wiley \& Sons.

Pint, Kris. Programs. in Peressut, Luca B, Forino, Imma, Postiglione Gennaro, and Rizzi Roberto. (2010). Interior Wor(I)ds. Torino: Umberto Allemandi\&C. 
Fuad, A.H., \& Yatmo, Y.A. / $5^{\text {th }}$ AicQoL2017Bangkok, 25-27 February 2017 / E-BPJ, 2(5), March 2017 (p.239-245)

Pressman S,D., Matthews K,A., Cohen S., Martire L, M., Scheier M., Baum A., Schultz R. (2009). Association of Enjoyable Leisure Activities With Psychological and Physical Well-Being. Journal Psychosomatic Medicine. 71(7), pp. 725-732. 